\title{
SCIDoC
}

\author{
International Journal of Dentistry and Oral Science (IJDOS) \\ ISSN: 2377-8075
}

\section{Actinic Cheilitis: Clinical, Pathological and Therapeutic Considerations}

Research Article

\author{
Diego Mauricio Bravo-Calderón ${ }^{1 *}$, María Paz Pinos-Gavilanes ${ }^{1}$, Daniel Esteban Pinos-Gavilanes ${ }^{2}$ \\ ${ }^{1}$ Faculty of Dentistry, University of Cuenca, Cuenca, Azuay, Ecuador. \\ ${ }^{2}$ Private Dental Clinic, Cuenca, Azuay, Ecuador.
}

Abstract

Actinic cheilitis (AC) is a chronic inflammation that affects more frequently to the lower lip and is considered as a potentially malignant disorder that could develop in to squamous cell carcinoma (SCC). AC is caused by excessive exposure to ultraviolet (UV) radiation, mainly sunlight radiation. Fair-skinned male patients, older than 50 years, who have worked outdoors or have had long-term sunlight exposure are more susceptible to develop this lesion. Their clinical manifestations are very varied; nevertheless, they are not related to the histopathological alterations that can be found. Histopathological diagnosis is the most important predictive factor of malignant transformation, depending on the severity of epithelial dysplasia. The characteristics of the AC are reviewed, so the clinician can provide optimal care to the patient and prevent lip cancer. The literature review was performed analyzing articles from PubMed, Science Direct, Google Scholar and Cochrane databases.

Keywords: Actinic Cheilitis; Oral Potentially Malignant Disorder; Lip; Ultraviolet Radiation.

\section{Introduction}

Actinic cheilitis (AC) is a chronic inflammatory condition of the lip, caused by an excessive exposure to ultraviolet radiation [1-3]. Ayres first described this lesion in 1923 and it is also known as: actinic cheilosis, solar cheilosis, actinic keratosis of the lips and sailor's lip [4-8]. According to the studied population, its prevalence varies between $0.45 \%$ and $43.2 \%$; and it is considered as a potentially malignant disorder, which can progress in to squamous cell carcinoma of the lip (LSCC) [1, 9-11]. It is estimated that 95\% of lip cancers originate from AC; therefore, it is extremely important that general dentists recognize this entity early $[2,7,12]$. This manuscript presents the clinicopathological characteristics of AC and reviews the information of its etiology, treatment and predictive factors of its evolution.

\section{Etiology}

Actinic cheilitis is caused by an excessive exposure to ultraviolet
(UV) radiation, both solar and artificial [1]. The lip is more susceptible to the action of UV rays than the skin, due to the epithelium of the lip is more delicate, and contains less keratin, melanin, sebaceous and sweat secretions [9]. Anatomically, the lower lip is more vulnerable to receiving high levels of radiation and consequently greater damage compared to its upper counterpart $[3$, $13,14]$.

Regarding the mechanism of action of UV rays, they are considered powerful carcinogens and disturb the immune function inducing immuno suppression; UV rays are classified according to their wavelength in: UVA1 $(340-400 \mathrm{~nm})$, UVA2 $(320-340 \mathrm{~nm})$, UV-B (280-320 nm) and UV-C (200-280 nm) [1, 15]. UV-A and UV-B have been related to the development of skin cancer, actinic cheilitis, and skin damage [1].

Specifically, UV-B radiation is necessary for the synthesis of vitamin D, but its excessive exposure produces direct damage to the DNA of epithelial cells, causing the DNA to act as a photophore

*Corresponding Author:

Diego Mauricio Bravo-Calderón,

School of Dentistry, University of Cuenca. El Paraíso Avenue and 10 de Agosto Avenue, Cuenca, Azuay, Ecuador.

Tel: 0059374051150 / 00593998272176

Email Id: diegom.bravoc@ucuenca.edu.ec

Received: March 03, 2021

Accepted: April 09, 2021

Published: April 14, 2021

Citation: Diego Mauricio Bravo-Calderón, María Paz Pinos-Gavilanes, Daniel Esteban Pinos-Gavilanes. Actinic Cheilitis: Clinical, Pathological and Therapeutic Considerations. Int J Dentistry Oral Sci. 2021;08(04):2319-2324. doi: http://dx.doi.org/10.19070/2377-8075-21000458

Copyright: Diego Mauricio Bravo-Calderón 2021. This is an open-access article distributed under the terms of the Creative Commons Attribution License, which permits unrestricted use, distribution and reproduction in any medium, provided the original author and source are credited. 
and absorbs the energy of the incident UV radiation, resulting in the formation of cyclobutane pyrimidine dimers [1, 15]. Thus, several studies performed on lip tissue have verified that UV-B radiation produces modifications in genes of important molecules, such as: p53, p21, p75NTR, Nanog, Nestin, HLA-G, VEGFR1 and VEGFR2; altering various biological processes including cell proliferation, migration, invasion and angiogenesis [1, 16-23]. In addition, to direct action on cellular DNA, UV-B rays also produce oxidative stress and inflammation [1].

Moreover, UV-A causes skin aging and indirect cellular damage through the oxidative pathway mediated by photosensitizers that result in the formation of reactive oxygen species, which turn in to a DNA alteration, increasing the carcinogenic action of UV-B rays $[1,24]$.

Finally, in relation to UV-C rays of solar origin, it has been observed that they are harmless for human health because they are filtered by the Earth's atmosphere and stratosphere [24]. However, excessive exposure to artificial UV-C radiation used for the sterilization of surfaces and air of spaces, shows temporary side effects such as irritation of the cornea, conjunctiva and skin, effects that disappear after 24 to 48 hours $[1,25,26]$. The possible effects of artificial UVC on lip keratinocytes need to be further studied.

\section{Clinical Features}

AC develops slowly, it is commonly confused as a characteristic of aging; initially, regions of dryness and cracking of the lip are observed, accompanied by attenuation of the demarcation between the lip mucosa and the lip skin but, without associated pain (Figure 1) [1, 3, 27]. As the lesion develops, the lip may become harder and experience ulceration, edema, erythema, pain, bleeding and even an accelerated growth of the entity can be verified $[10,13,28]$.

AC affects the lower lip in $95 \%$ of cases, due to its higher exposure to solar radiation $[1,9,11,23]$. Regarding the sex of the patient, it is important to indicate that the lesion is more frequent in men than in women, possibly because men execute jobs that involve more activity outdoors and an excessive degree of sun exposure; further more, it is likely that women use lipstick as a protective agent $[8,9,13,24,29-36]$.

The majority of patients with AC are light-skinned phototype, between type I and II according to the Fitzpatrick classification [37]
(Table 1). These skin tones are pale and lack of melanin, making them more susceptible to damage from UV rays; although, cases of this lesion have been identified in dark-skinned people, but their risk is lower $[22,24,30,32-34,37-39]$.

Other factors associated with the development of this lesion are: age over 50 years, working outdoors, smoking, a history of skin cancer such as melanoma or non-melanoma, previous LSCC, alcohol consumption, immunosuppression and genetic predisposition $[1,9,12,13,36,40]$.

\section{Histopathology}

The epithelium is characterized by the presence of hyperortokeratosis or hyperparakeratosis, it can be atrophic or acanthotic, and can also show different degrees of dysplasia [27]. The connective tissue shows an amorphous or granular basophilic material called solar elastosis, which represents alterations of the collagen and elastic fibers due to the action of UV light, in addition, a variable amount of chronic inflammatory infiltrate and dilated blood vessels are identified (Figure 2) [24, 27, 30, 41]. Oral epithelial dysplasia is a spectrum of architectural and cytological epithelial changes caused by genetic alterations and is classified as mild, moderate, and severe or carcinoma in situ according to the number of epithelial thirds affected and the severity of the architectural alterations and/or cytological atypia [42]. Mild dysplasia is defined by atypia limited to the basal third, moderate dysplasia by extension to the middle third and severe dysplasia or carcinoma in situ by the presence of alterations up to the upper third; however, a marked atypia in the basal third of the epithelium is sufficient to grade as moderate or severe dysplasia at the time of diagnosis [42]. This classification has little intra-and interobserver reproducibility, which is why the World Health Organization recommends a consensus among pathologists to achieve reproducibility at the time of diagnosis with respect to dysplasia in the oral mucosa [42].

\section{Prognosis}

Between 3-30\% of AC cases can transform in to invasive SCC, in periods of 1 to 30 years according to different studies $[2,3,12,31$, 33]. Thus, the prognosis of AC is variable and depends mainly on the degree of epithelial dysplasia and on changes in the patient's habits such as reduction in sun exposure, use of sunscreen, hats and caps $[9,10]$.

Regarding microscopically verifiable prognostic factors, it is im-

Table 1. Fitzpatrick classification of skin phototypes based on sunburn and tanning trend.

\begin{tabular}{|c|c|}
\hline Fitzpatrick Skin Phototype & Skin reaction \\
\hline I - Fair-skinned & Always burn, never tan \\
\hline II - Fair-skinned & $\begin{array}{c}\text { Usually burn, tan less than average } \\
\text { (with difficulty) }\end{array}$ \\
\hline III - Fair-skinned & $\begin{array}{c}\text { Sometimes mild burn, tan about } \\
\text { average }\end{array}$ \\
\hline IV - Light brown skin & $\begin{array}{c}\text { Rarely burn, tan more than average } \\
\text { (with ease) }\end{array}$ \\
\hline V - Brown skin & Rarely burns, tans deeply \\
\hline VI - Dark brown/black skin & Never burns, tans deeply \\
\hline
\end{tabular}


portant to note that the histological changes of AC are not evenly distributed in the vermilion of the lip, even in cases where the clinical presentation of AC is homogeneous [3]. The presence of the epithelial dysplasia is the principal predictive factor of malignant transformation of this oral potentially malignant lesion, transformation rates of $24.98 \%$ have been verified in cases with severe dysplasia, $12.57 \%$ in cases with moderate dysplasia, and $5.23 \%$ in lesions with mild dysplasia $[42,43]$. Together, these reasons reinforce the necessity to perform the histopathological analysis of any suspicious lesion [?].

Otherwise, although the presence of dysplasia is correlated to the development of SCC, many lesions do not progress to malignancy, being low the reproducibility of the diagnosis of dysplasia the cause of this lack of accuracy as a prognostic factor [42, 44, 45]. In this context, different molecules have been analyzed as possible biomarkers for the prognosis of AC, including:

The p53 protein that regulates the G1/S checkpoint of the cell cycle, mutations in TP53 gene make p53 unable to control cell proliferation, resulting in inefficient DNA repair and allowing many cells exposed to mutagens to replicate the genetic material damaged, spreading the changes incorporated in to the genome $[1,3] .90 \%$ of SCC cases have specific UV mutations of the TP53 gene, consequently its overexpression significantly increases the risk of AC transforming to a SCC; also, the expression of p53 leads to an increase in the expression of p21, suggesting that it may also be involved in carcinogenesis processes [16].

Cancer stem cells (CMCs) that represent a small and rare subpopulation of cells capable of self-renewal, they have an unlimited replication potential and a unique ability to initiate and maintain tumor growth, for this reason are also known as cell tumor initiators [18]. Some surface markers help us to identify CMCs, such as the p75 neurotrophin receptor (p75NTR) which is overexpressed as the degree of epithelial dysplasia increases in cases of $\mathrm{AC}$ and LSCC [18].

Nanog protein is a transcription factor present in embryonic stem cells, which can modulate the proliferation, invasiveness and metastasis of neoplastic cells [46]. Nestin protein is considered a biomarker to identify CMCs in epithelial neoplasms and has key roles in the differentiation, proliferation, migration, invasion, metastasis and survival of malignant neoplastic cells, by regulating the cytoskeleton and progenitor cells [47]. Both Nanog and Nestin have shown a positive relationship with CMCs, in cases of AC there is overexpression of these proteins [19].

HLA-G protein or human leukocyte antigen $G$ is an immune control protein that is dysregulated in the presence of tumors and precursor disorders; cases of AC have exhibited higher expressions levels of this protein when compared to normal epithelium of the lip [21]. In addition, Langerhans CD1a + cells are significantly reduced in cases of AC compared to normal oral epithelium [20].

The increase in vascularization is significant during the transition from normal oral mucosa to different degrees of epithelial dysplasia, receptors for vascular endothelial growth factor such as VEGFR1 and VEGFR2 are over expressed in AC epithelium [22, 23].

\section{Treatment}

The main objective of the treatment of $\mathrm{AC}$ is the removal of the altered epithelium, which can be achieved by non-surgical and surgical techniques.

\section{Non-surgical Treatments}

\section{5- Fluorouracil (5-FU)}

5-FU is an antimetabolite drug used as a systemic chemotherapeutic agent; it blocks DNA synthesis by inhibiting the enzyme thymidylate synthase [27]. This agent affects neoplastic cells due to their increased metabolic activity [6]. For the management of AC it has been used topically, several presentations are available (solution, cream and microsponge cream) and different concentrations of $0.5 \%$ to $5 \%$; the use of one to two times a day is suggested for a period of several weeks [6]. Immediate side effects include erythema, edema, ulceration and pain of the lips, in few cases difficulty eating and speaking; these symptoms often persist throughout the course of therapy and can cause a decrease in patient adherence to prescribed treatment $[6,48]$. With the aim of reducing the side effects of 5-FU, its application was proposed only once a week; however, efficacy in eliminating the lesion was not verified clinically or pathologically [49]. Further more, Robinson (1989) found that, although this drug can clinically eliminate AC lesions, recurrent areas with the presence of epithelial dysplasia can be seen histologically in $60 \%$ of cases [48]. The recurrence rate presented with 5-FU reinforces the need for long-term monitoring of patients treated with this drug.

\section{Imiquimod}

Imiquimod works as an immune modulator that binds to the Tolllike receptor 7 (TLR-7), its activation provokes intracellular signaling, which leads to the release of interferon and pro-inflammatory cytokines; inducing apoptosis of abnormal cells [27]. Topical application of $5 \%$ imiquimod has side effects similar to 5 -FU that include: erythema, edema, suppuration, crusting, erosion, superficial ulceration and pain that can be mild to severe $[6,27]$. Due to the side effects, patient compliance can become a major factor impairing successful imiquimod treatment [6]. The application of imiquimod three times per week over the course of four to six weeks, demonstrated to be clinical effectively but the histological recurrence has not been proven yet $[6,50,51]$.

\section{Diclofenac}

Diclofenac is a non-steroidal anti-inflammatory agent that acts by decreasing the dynamics of the proliferative cell cycle by inhibiting the formation of prostaglandins $[6,27]$. Topical application has been proposed as a less aggressive treatment alternative, 3\% diclofenac gel for a period of 6 weeks has proven to be efficient [52]. Side effects can include edema, erythema and a burning sensation [52]. However, new studies are necessary to know the recurrence after the application of this agent.

\section{Photodynamic Therapy}

Photodynamic therapy (PDT) consists of application of an photo sensitizing agent that is activated by a visible light source and pro- 
duces oxygen free radicals, these destabilize the cell membrane and organelles, inducing apoptosis [53]. During treatment, first, crusts and scales are carefully removed from the lip; a photosensitizer such as 5-aminolevulinic acid (5-ALA) is applied locally, this takes approximately two hours to be absorbed by potentially malignant cells, its intracellular presence allows the selective absorption of light and subsequently the destruction of the injured tissue $[6,54]$. PDT may have some limitations because it can be complex, time consuming, expensive, and it produces side effects such as erythema, edema, burning sensation and pain in the lip as it is a very sensitive area [54]. Daylight PDT is an effective alternative conventional therapy, pain is minimal or nonexistent and has a lower cost of treatment $[54,55]$. However, the persistence of dysplasia after PDT therapy has been demonstrated, with a high rate of recurrence up to $62 \%$ [56].

\section{Surgical Treatments}

\section{Vermilionectomy}

Vermilionectomy is considered an excisional biopsy because consists of the complete removal of all the epithelium that covers the lip, using a scalpel $[3,6]$. There are variations of this procedure, for example: a simple vermilionectomy involves removal of the vermilion only at the level of the orbicular muscles of the mouth, while a modified vermilionectomy may include removal of adjacent glands and muscle tissue [6]. It is considered an invasive treatment and several side effects have been described, including delayed re-epithelialization, initially non-esthetic appearance of the lip, pain in the healing phase, edema, secondary infection, scars, paresthesia and dysesthesia and necrosis [27, 29, 48]. Despite the adverse effects, this is the treatment of choice, demonstrating excellent results with complete clinical and pathological resolution of the lesion and because is the only therapy that generates a surgical specimen in which can be performed the microscopically verification of the dysplasia or the early detection of a possible invasive tumor $[2,3,6,48,51]$.

\section{Carbon Dioxide Laser Ablation}

The carbon dioxide (CO2) laser creates an infrared light with a wavelength of $10.600 \mathrm{~nm}$ that produces a thermal effect on the injured tissue, heating intracellular and extracellular water to $100^{\circ} \mathrm{C}$, which causes vaporization and alteration of the cell membrane and subsequently leads to cell death [6]. The treated epithelium is removed with a moistened cotton swab or gauze [6]. A distinctive advantage of CO2 laser therapy is that it is a procedure that allows direct visualization of the lip during treatment because it is a bloodless procedure, leaves the underlying muscle intact, also has fewer adverse effects than vermilionectomy $[6,57,58]$. Furthermore, the efficacy of the $\mathrm{CO} 2$ laser has high effectiveness rates with values similar to those obtained through vermilionectomy, and investigations with post-therapeutic biopsies have shown few recurrences of AC treated with CO2 laser [6, 48, 59, 60].

\section{Cryosurgery}

Focal lesions of AC has been successfully treated by cryosurgery since the smooth surface and moisture of the mucous membranes allow fast freezing, it is done by applying liquid nitrogen to the lesion, this acts at the cellular level, causing crystallization and subsequent cell disruption by metabolic flux; it also functions at the vascular level by causing thrombosis, ischemia, and cell necrosis [61]. The advantages of cryosurgery are several, it is an inexpensive treatment and does not require much operator skill, it can be performed without local anesthesia and it is fast; however, a disadvantage is that there is no standardization for the application of cryogen (using a spray, flat attachment, or cotton tip applicator) and application time [6]. Possible adverse effects of cryosurgery include postoperative edema, pain during and after treatment, local irritation, redness, headache induction, long-term scarring, hyperpigmentation, hypopigmentation, and local neuropathy $[6,27]$. Another disadvantage of cryosurgery is that it does not eliminate all the lesions treated; Lubritz et al. (1989) in their study found a recurrence of $3.8 \%[6,62]$.

\section{Electrosurgery}

Electrosurgery is also a relatively inexpensive, simple, and useful therapeutic option for the treatment of focally localized AC [6]. In this method, an electrode is used to apply an electrical current to the labial surface previously locally anesthetized, then the charred epithelium is removed by means of a gauze moistened with saline solution $[6,58]$. The disadvantages of this technique includes a prolonged healing time that on average is 8 days longer when compared to areas treated by $\mathrm{CO} 2$ laser; in addition, the patient may manifest a burning sensation and the possible formation of scars in the adjacent tissue $[57,58]$. Regarding recurrence rates, a study by Laws et al. (2000) revealed that only two of six patients showed histological improvement after treatment with electrosurgery; further long-term studies are needed on the clinical and histological efficacy of this modality $[6,58]$.

In summary, the selection of therapy for $\mathrm{AC}$ should be carried out individually for each case, considering the possible adverse effects, the aesthetic wishes of the patient and above all; scientific evidence and microscopically findings obtained from the analysis of incisional biopsies [6,51]. Therapies that are more aggressive should be considered in extensive AC, with poorly defined borders and/or with severe dysplasia, while, conservative methods can be selected for those focal cases, without dysplasia [51]. Further more, regardless of the treatment carried out, long-term postoperative follow-up of patients diagnosed with AC should be performed, with visits every 6 months for the first 2 years and subsequent annual controls [2, 6].

\section{Conclusion}

In conclusion, considering that actinic cheilitis is a potentially malignant disorder; the dentist must attempt its early detection, paying particular attention to the clinical examination of the lip, since suspicious lesions must be analyzed microscopically to establish the definitive diagnosis. The main therapeutic options are $\mathrm{CO} 2$ laser ablation and vermilionectomy, due to their high effectiveness and, in the case of vermilionectomy, the possibility of the histopathological study of the epithelium. Finally, patient orientation regarding preventive measures for sun protection and their longterm post-therapeutic monitoring is mandatory.

\section{References}

[1]. Dancyger A, Heard V, Huang B, Suley C, Tang D, Ariyawardana A. Malignant transformation of actinic cheilitis: A systematic review of observational studies. J Investig Clin Dent. 2018 Nov;9(4):e12343. Pubmed PMID: 
29863311.

[2]. Carvalho MV, de Moraes SLD, Lemos CAA, Santiago Júnior JF, Vasconcelos BCDE, Pellizzer EP. Surgical versus non-surgical treatment of actinic cheilitis: A systematic review and meta-analysis. Oral Dis. 2019 May;25(4):972981. Pubmed PMID: 29908101.

[3]. Vieira RA, Minicucci EM, Marques ME, Marques SA. Actinic cheilitis and squamous cell carcinoma of the lip: clinical, histopathological and immunogenetic aspects. An Bras Dermatol. 2012 Jan-Feb;87(1):105-14. Pubmed PMID: 22481658

[4]. AYRES S. Chronic actinic cheilitis. Journal of the American Medical Association. 1923 Oct 6;81(14):1183-6.

[5]. Lugović-Mihić L, Pilipović K, Crnarić I, Šitum M, Duvančić T. Differential Diagnosis of Cheilitis - How to Classify Cheilitis? Acta Clin Croat. 2018 Jun;57(2):342-351. Pubmed PMID: 30431729.

[6]. Shah AY, Doherty SD, Rosen T. Actinic cheilitis: a treatment review. Int J Dermatol. 2010 Nov;49(11):1225-34. Pubmed PMID: 20964646.

[7]. Osorio $\mathrm{CH}$, Palma BF, Cartes-Velásquez R. Queilitis actínica: aspectos histológicos, clínicos y epidemiológicos. Revista cubana de estomatología. 2016;53(2):45-55.

[8]. Gonzaga AKG, Mafra RP, da Silva LP, de Almeida Freitas R, de Souza LB, Pinto LP. Actinic cheilitis: Morphometric parameters and its relationship with the degree of epithelial dysplasia. Acta Histochem. 2020 Jan;122(1):151452. Pubmed PMID: 31558280

[9]. de Santana Sarmento DJ, da Costa Miguel MC, Queiroz LM, Godoy GP, da Silveira EJ. Actinic cheilitis: clinicopathologic profile and association with degree of dysplasia. Int J Dermatol. 2014 Apr;53(4):466-72. Pubmed PMID: 24320079

[10]. Santos RFD, Oliveira RL, Gallottini M, Caliento R, Sarmento DJS. Prevalence of and Factors Associated with Actinic Cheilitis in Extractive Mining Workers. Braz Dent J. 2018 Mar-Apr;29(2):214-221. Pubmed PMID: 29898071 .

[11]. Maia HC, Pinto NA, Pereira Jdos S, de Medeiros AM, da Silveira ÉJ, Miguel MC. Potentially malignant oral lesions: clinicopathological correlations. Einstein (Sao Paulo). 2016 Jan-Mar;14(1):35-40. Pubmed PMID: 27074232.

[12]. Lai M, Pampena R, Cornacchia L, Pellacani G, Peris K, Longo C. Treatments of actinic cheilitis: A systematic review of the literature. J Am Acad Dermatol. 2020 Sep;83(3):876-887. Pubmed PMID: 31400450.

[13]. Markopoulos A, Albanidou-Farmaki E, Kayavis I. Actinic cheilitis: clinical and pathologic characteristics in 65 cases. Oral Dis. 2004 Jul;10(4):212-6. Pubmed PMID: 15196142

[14]. Rodriguez-Blanco I, Florez Á, Paredes-Suárez C, Rodríguez-Lojo R, González-Vilas D, Ramírez-Santos A, et al. Use of lip photoprotection in patients suffering from actinic cheilitis. Eur J Dermatol. 2019 Aug 1;29(4):383-386. Pubmed PMID: 31475909.

[15]. Suozzi K, Turban J, Girardi M. Cutaneous Photoprotection: A Review of the Current Status and Evolving Strategies. Yale J Biol Med. 2020 Mar 27;93(1):55-67. Pubmed PMID: 32226337.

[16]. Lopes ML, de Oliveira DH, Sarmento DJ, Queiroz LM, Miguel MC, da Silveira ÉJ. Correlation between cell cycle proteins and hMSH2 in actinic cheilitis and lip cancer. Arch Dermatol Res. 2016 Apr;308(3):165-71. Pubmed PMID: 26842232

[17]. Correa GT, Bernardes VF, de Sousa SF, Diniz MG, Salles JM, Souza RP, et al. Lip cancer and pre-cancerous lesions harbor TP53 mutations, exhibit allelic loss at 9p, 9q, and 17p, but no BRAFV600E mutations. Tumour Biol. 2015 Nov;36(11):9059-66. Pubmed PMID: 26084614.

[18]. Custódio M, Pelissari C, Santana T, Trierveiler M. Expression of cancer stem cell markers CD44, ALDH1 and p75NTR in actinic cheilitis and lip cancer. Eur Arch Otorhinolaryngol. 2018 Jul;275(7):1877-1883. Pubmed PMID: 29779037.

[19]. Scotti FM, Mitt VC, Vieira DS, Biz MT, Castro RG, Modolo F. Expression of stem cell markers Nanog and Nestin in lip squamous cell carcinoma and actinic cheilitis. Oral Dis. 2018 Oct;24(7):1209-1216. Pubmed PMID: 29761881.

[20]. Gomes JO, de Vasconcelos Carvalho M, Fonseca FP, Gondak RO, Lopes MA, Vargas PA. CD1a+ and CD83+ Langerhans cells are reduced in lower lip squamous cell carcinoma. J Oral Pathol Med. 2016 Jul;45(6):433-9. Pubmed PMID: 26661374.

[21]. Lopes MLDS, Gonzaga AKG, Mosconi C, Palomino GM, Mendonça EF, Batista AC, et al. Immune response and evasion mechanisms in lip carcinogenesis: An immunohistochemical study. Arch Oral Biol. 2019 Feb;98:99107. Pubmed PMID: 30468994.

[22]. Barbosa NG, Souza LB, Nonaka CF, Silveira EJ. Evaluation of hypoxia, angiogenesis, and lymphangiogenesis in actinic cheilitis. Int J Dermatol. 2016 Nov;55(11):e573-e578. Pubmed PMID: 27420649.

[23]. Ariotti C, Wagner VP, Salvadori G, Carrard VC, Martins MA, da Cunha Filho JJ, et al. VEGFR1 and VEGFR2 in lip carcinogenesis and its association with microvessel density. Tumour Biol. 2015 Sep;36(9):7285-92. Pub- med PMID: 25895461.

[24]. Guil PM. Parámetros de riesgo de la queilitis actínica crónica. Editorial de la Universidad de Granada; 2009.

[25]. Buonanno M, Welch D, Shuryak I, Brenner DJ. Far-UVC light (222 nm) efficiently and safely inactivates airborne human coronaviruses. Sci Rep. 2020 Jun 24;10(1):10285. Pubmed PMID: 32581288.

[26]. Zaffina S, Camisa V, Lembo M, Vinci MR, Tucci MG, Borra M, et al. Accidental exposure to UV radiation produced by germicidal lamp: case report and risk assessment. Photochem Photobiol. 2012 Jul-Aug;88(4):1001-4. Pubmed PMID: 22458545.

[27]. Salgueiro AP, de Jesus LH, de Souza IF, Rados PV, Visioli F. Treatment of actinic cheilitis: a systematic review. Clin Oral Investig. 2019 May;23(5):20412053. Pubmed PMID: 31011833.

[28]. Kwon NH, Kim SY, Kim GM. A case of metastatic squamous cell carcinoma arising from actinic cheilitis. Ann Dermatol. 2011 Feb;23(1):101-3. Pubmed PMID: 21738376.

[29]. Castinneiras I, Del Pozo J, Mazaira M, Rodríguez-Lojo R, Fonseca E. Actinic cheilitis: evolution to squamous cell carcinoma after carbon dioxide laser vaporization. A study of 43 cases. J Dermatolog Treat. 2010 Jan;21(1):49-53. Pubmed PMID: 19418331.

[30]. Cavalcante AS, Anbinder AL, Carvalho YR. Actinic cheilitis: clinical and histological features. J Oral Maxillofac Surg. 2008 Mar;66(3):498-503. Pubmed PMID: 18280383.

[31]. de Oliveira Bezerra HI, Gonzaga AKG, da Silveira ÉJD, de Oliveira PT, de Medeiros AMC. Fludroxycortide cream as an alternative therapy for actinic cheilitis. Clin Oral Investig. 2019 Oct;23(10):3925-3931. Pubmed PMID: 30673866.

[32]. Gonzaga AKG, de Oliveira PT, da Silveira ÉJD, Queiroz LMG, de Medeiros AMC. Diclofenac sodium gel therapy as an alternative to actinic cheilitis. Clin Oral Investig. 2018 Apr;22(3):1319-1325. Pubmed PMID: 28986686.

[33]. Lopes ML, Nonaka CF, Queiroz LM, de Souza LB, Miguel MC, da Silveira EJ. Pattern of galectins expression in actinic cheilitis with different risks of malignant transformation. J Oral Pathol Med. 2016 Sep;45(8):621-6. Pubmed PMID: 26711374.

[34]. Mello FW, Melo G, Modolo F, Rivero ER. Actinic cheilitis and lip squamous cell carcinoma: Literature review and new data from Brazil. J Clin Exp Dent. 2019 Jan 1;11(1):e62-e69. Pubmed PMID: 30697396.

[35]. Orozco P, Vásquez S, Venegas B, Rivera C. Prevalencia de queilitis actínica en trabajadores expuestos a radiación ultravioleta en Talca, Chile. Revista clínica de periodoncia, implantología y rehabilitación oral. 2013 Dec 1;6(3):127-9.

[36]. Ríos P, Maldonado C, Norambuena P, Donoso M. Prevalencia de queilitis actínica en pescadores artesanales, Valdivia, Chile. International journal of odontostomatology. 2017 Jun;11(2):192-7.

[37]. Fitzpatrick TB. The validity and practicality of sun-reactive skin types I through VI. Arch Dermatol. 1988 Jun;124(6):869-71. Pubmed PMID: 3377516.

[38]. Rodríguez-Blanco I, Flórez Á, Paredes-Suárez C, Rodríguez-Lojo R, González-Vilas D, Ramírez-Santos A, et al. Actinic Cheilitis: Analysis of Clinical Subtypes, Risk Factors and Associated Signs of Actinic Damage. Acta Derm Venereol. 2019 Sep 1;99(10):931-932. Pubmed PMID 31197386.

[39]. Muse ME, Crane JS. Actinic Cheilitis. StatPearls [Internet]. 2020 Aug 8.

[40]. Bentley JM, Barankin B, Lauzon GJ. Paying more than lip service to lip lesions. Can Fam Physician. 2003 Sep;49:1111-6. Pubmed PMID: 14526863.

[41]. Santana T, Matuck B, Tenório JR, Braga MM. Can immunohistochemical biomarkers distinguish epithelial dysplasia degrees in actinic cheilitis? A systematic review and meta-analysis. Med Oral Patol Oral Cir Bucal. 2020 Jan 1;25(1):e106-e116. Pubmed PMID: 31880283

[42]. El-Naggar AK, Chan JK, Grandis JR, Takata T, Slootweg PJ, editors. WHO classification of head and neck tumours. International Agency for Research on Cancer (IARC); 2017.

[43]. Dong Y, Chen Y, Tao Y, Hao Y, Jiang L, Dan H, et al. Malignant transformation of oral leukoplakia treated with carbon dioxide laser: a meta-analysis. Lasers Med Sci. 2019 Feb;34(1):209-221. Pubmed PMID: 30443884.

[44]. Nagata G, Santana T, Queiroz A, Caramez RH, Trierveiler M. Evaluation of epithelial dysplasia adjacent to lip squamous cell carcinoma indicates that the degree of dysplasia is not associated with the occurrence of invasive carcinoma in this site. J Cutan Pathol. 2018 May 8. Pubmed PMID: 29740875.

[45]. Pilati S, Bianco BC, Vieira D, Modolo F. Histopathologic features in actinic cheilitis by the comparison of grading dysplasia systems. Oral Dis. 2017 Mar;23(2):219-224. Pubmed PMID: 27759902.

[46]. Watanabe M, Ohnishi Y, Inoue H, Wato M, Tanaka A, Kakudo K, et al. NANOG expression correlates with differentiation, metastasis and resistance to preoperative adjuvant therapy in oral squamous cell carcinoma. Oncol Lett. 2014 Jan;7(1):35-40. Pubmed PMID: 24348816.

[47]. Neradil J, Veselska R. Nestin as a marker of cancer stem cells. Cancer Sci. 2015 Jul;106(7):803-11. Pubmed PMID: 25940879. 
[48]. Robinson JK. Actinic cheilitis. A prospective study comparing four treatment methods. Arch Otolaryngol Head Neck Surg. 1989 Jul;115(7):848-52. Pubmed PMID: 2736096.

[49]. Wright K, Dufresne R. Actinic cheilitis. Dermatol Surg. 1998 Apr;24(4):4901. Pubmed PMID: 9568209.

[50]. Smith KJ, Germain M, Yeager J, Skelton H. Topical 5\% imiquimod for the therapy of actinic cheilitis. J Am Acad Dermatol. 2002 Oct;47(4):497-501. Pubmed PMID: 12271290.

[51]. Varela-Centelles P, Seoane-Romero J, García-Pola MJ, Leira-Feijoo Y, Seoane-Romero JM. Therapeutic approaches for actinic cheilitis: therapeutic efficacy and malignant transformation after treatment. Int J Oral Maxillofac Surg. 2020 Oct;49(10):1343-1350. Pubmed PMID: 32171621.

[52]. Ulrich C, Forschner T, Ulrich M, Stockfleth E, Sterry W, Termeer C. Management of actinic cheilitis using diclofenac 3\% gel: a report of six cases. $\mathrm{Br} \mathrm{J}$ Dermatol. 2007 May;156 Suppl 3:43-6. Pubmed PMID: 17488406.

[53]. Chaves YN, Torezan LA, Lourenço SV, Neto CF. Evaluation of the efficacy of photodynamic therapy for the treatment of actinic cheilitis. Photodermatol Photoimmunol Photomed. 2017 Jan;33(1):14-21. Pubmed PMID: 27864997.

[54]. Levi A, Hodak E, Enk CD, Snast I, Slodownik D, Lapidoth M. Daylight photodynamic therapy for the treatment of actinic cheilitis. Photodermatol Photoimmunol Photomed. 2019 Jan;35(1):11-16. Pubmed PMID: 30066408 .

[55]. Wiegell SR, Wulf HC, Szeimies RM, Basset-Seguin N, Bissonnette R, Gerritsen MJ, et al. Daylight photodynamic therapy for actinic keratosis: an international consensus: International Society for Photodynamic Therapy in Dermatology. J Eur Acad Dermatol Venereol. 2012 Jun;26(6):673-9. Pubmed PMID: 22211665.

[56]. Berking C, Herzinger T, Flaig MJ, Brenner M, Borelli C, Degitz K. The efficacy of photodynamic therapy in actinic cheilitis of the lower lip: a prospec- tive study of 15 patients. Dermatol Surg. 2007 Jul;33(7):825-30. Pubmed PMID: 17598848.

[57]. Kim SM, Myoung H, Eo MY, Cho YJ, Lee SK. Proper management of suspicious actinic cheilitis. Maxillofac Plast Reconstr Surg. 2019 Apr 9;41(1):15. Pubmed PMID: 31032237.

[58]. Laws RA, Wilde JL, Grabski WJ. Comparison of electrodessication with CO2 laser for the treatment of actinic cheilitis. Dermatol Surg. 2000 Apr;26(4):349-53. Pubmed PMID: 10759824.

[59]. Whitaker DC. Microscopically proven cure of actinic cheilitis by CO2 laser. Lasers Surg Med. 1987;7(6):520-3. Pubmed PMID: 3431329.

[60]. de Godoy Peres FF, Aigotti Haberbeck Brandāo A, Rodarte Carvalho Y, Dória Filho U, Plapler H. A study of actinic cheilitis treatment by two lowmorbidity CO2 laser vaporization one-pass protocols. Lasers Med Sci. 2009 May;24(3):375-85. Pubmed PMID: 18553116.

[61]. Ishida CE, Ramos-e-Silva M. Cryosurgery in oral lesions. Int J Dermatol. 1998 Apr;37(4):283-5. Pubmed PMID: 9585902.

[62]. Lubritz RR, Smolewski SA. Cryosurgery cure rate of premalignant leukoplakia of the lower lip. J Dermatol Surg Oncol. 1983 Mar;9(3):235-7. Pubmed PMID: 6826879. 